\title{
Juridical Study on Implementation of Village Chairman Using E- Voting Method
}

\section{Arif Hijrah Saputra* ${ }^{*}$ and Widayati**)}

*) Student of Master of Law, Faculty of Law, Universitas Islam Sultan Agung (UNISSULA) Semarang, E-mail: arifhijrah@gmail.com

${ }^{* *}$ Faculty of Law, Universitas Islam Sultan Agung (UNISSULA) Semarang

\begin{abstract}
.
Election for Village Heads using the e-voting method is an alternative to the implementation of general elections which are supported by electronic devices, which in general, the election of Village heads in many districts in Indonesia still uses the conventional method of voting by means of vote on photos/signs of candidate image. The purpose of this study was to determine how the implementation of village head elections using the e-voting method, the supporting and inhibiting factors and what are the prospects for implementation in the future. The approach method in this research is juridical empirical, namely research that refers to the legal norms and principles contained in the statutory regulations which are adjusted to the actual conditions. Based on the results of the research, it can be concluded that the implementation of the Village Head Election through e-voting does not exist to a good democratic system where the implementation of the Village Head election policy is not based on the will and will of the people. The supporting factor in implementing the village head election through the e-voting method is the formation election committee, village head election costs, witnesses, and the implementation of voting. The inhibiting factors are the lack of communication from the organizers to the public, the lack of availability of resources, the legality of procuring e-voting tools simultaneously, the legality of civil servants as experts/programmers/e-voting operators, the Legitimacy of Voters Boxes in the e-voting Pilkades, and Opportunities for Disputes in the Village Head Election, the prospect of future implementation, namely utilizing the current development of information technology, has brought major changes for humans, including e-voting. The use of computer technology in the implementation of voting is known as electronic voting (e-voting). E-voting is a method of voting in general elections using electronic devices. E-voting will be an option in future elections.

Keywords: Implementation; Village; Election; E-Voting.
\end{abstract}

\section{Introduction}

In the current era of globalization, it has made the world seem borderless, the divides between one country and another become virtual (borderless state). This happens because the development of communication technology is increasingly sophisticated and the next consequence is that the world will be controlled by those who are able to master information technology. ${ }^{1}$

The reform era was marked by the replacement of Act No. 22 of 1999 became Act No. 32 of 2004 concerning Regional Government which is independent can regulate and manage government affairs according to the principle of autonomy in

${ }_{1}^{1}$ Maryanto, SH., MH. (2011). Urgensi Pembaharuan Hukum Indonesia Berdasarkan Nilai-Nilai Pancasila, Jurnal Hukum Unissula, Jurnal Hukum, Vol XXV, No. 1, April 2011. 
order to accelerate the welfare of its citizens through enhancement and empowerment of democratic principles. Village Head Election with the latest regulations as referred to in Law Number 6 of 2014 concerning villages which reads Village is a legal community unit that has territorial boundaries that are authorized to regulate and administer government affairs, the interests of the local community based on community initiative, rights of origin and/or traditional rights recognized and respected in the government system of the Republic of Indonesia.

In the millennial era, several regions in Indonesia have started to replace the manual election method by using the e-voting method as an alternative to organizing a general election system that is more effective and efficient than before which uses a conventional system that has even been implemented at the lowest level, namely the election of hamlet heads and village heads. .

One of them is Pemalang Regency, that as an illustration, for example the Village Head Election in Pemalang Regency, a number of 172 Villages have carried out simultaneous Pikades using e-voting and e-verification on September 2, 2018 to November 4, 2018. However, in its implementation there are several problems in its operation, resulting in very long and dense queues at the implementation of the Village Head Election due to ineffective services. ${ }^{2}$

\section{Research Methods}

The method used in this research is empirical juridical research, which refers to a legal phenomenon based on legal norms and principles contained in statutory regulations and court decisions and adjusted to actual conditions. ${ }^{3}$ The specification of this research is descriptive analytical research, which is a study that seeks to describe legal, legal issues and study them or analyze them according to the needs of the research concerned, namely the implementation of the Pilkades using the e-voting method in Pemalang district. The data analysis used is qualitative analysis, where after collecting data, a comprehensive, systematic processing, analyzing and construction is carried out by explaining the relationship between various types of data. Furthermore, the data is completed and processed, then analyzed descriptively with the approach to the theory of the rule of law and theory of the democratic state.

\section{Results and Discussion}

The Village Head Election is carried out by punching out a picture of the Village Head Candidate. Lately there is a tendency for Pilkades to be held simultaneously in one district/city, facilitated by the Regional Government. This is

2Bachri, Saiful. (2018). Bupati Pemalang Kritik Pilkades Voting Elektronik. Retrieved from Suara Merdeka website: https://www.suaramerdeka.com/news/baca/121237/bupati-pemalang-kritik3Ishaaq. (2017). Metode Penelitian Hukum Penulisan Skripsi, Tesis, Serta Desertasi, Alfabeta, Bandung, p. 66 
done so that its implementation is more effective, efficient and more coordinated from the security side. ${ }^{4}$

The process of organizing democratic elections really requires the participation of the public as the owner of voting rights. Several important things related to community participation, namely; First, to increase citizens' interest and concern for the election administration, as well as knowledge/information about the election implementation process. Second, the implementation of Party sovereignty rests with the members, people's sovereignty, human rights in the political field, recognition of the legitimacy of political parties, the legitimacy of state administrators (legislative and executive, both at the national and regional levels), and the political system in general. Third, to ensure fair elections (submit the results of monitoring and complaints of alleged violations of election legislation), and ensure the integrity of election results (quick count of election results). ${ }^{5}$

Whereas the implementation of the Village Head Election in Pemalang Regency is based on the village typology, namely traditional villages, transitional villages and modern villages. In this case, it is to see whether the Pilkades activity in Pemalang Regency is a phenomenon that fully fulfills the ideal criteria of democracy or not. Pilkades is a political event at the village level which shows that village communities are people who have been directly involved in politics. The election of the village head is a form of local politics at the village level that is in line with realizing village autonomy. The government also maintains and supervises village autonomy given by the government through Government Regulation Number 43 of 2014 concerning Villages. ${ }^{6}$

In Pemalang District, there is still identification as a transitional village. Apart from being in the border area between Pemalang Regency, which partly has rural and urban characteristics, this transitional village has begun to be able to independently carry out its own household affairs. In addition, the management of the government is quite orderly even though it is not well organized. Likewise, there is a role for the BPD in organizing and mobilizing village community participation in political and government activities in the village.

Law as a tool is a rule that can prevent the authorities from acting arbitrarily. Law is the boundaries of freedom between individuals and rulers in every interaction until the law becomes a protection and guarantee for the creation of public order. Without the law, chaos and arbitrariness will arise. In Vivian Bose's

\footnotetext{
4 Kuncoro, Adi. (2019). Perbandingan Prosedur Pemilihan Kepala Desa Berdasarkan Peraturan Daerah Kabupaten Grobogan Nomor 6 Tahun 2016 \& Menurut Undang-Undang Nomor 6 Tahun 2014 (Studi Kasus di Desa Rawoh Kec. Karang-Rayung Kab.Grobogan). Undergraduate thesis, Universitas Islam Sultan Agung, p. 4.

${ }^{5}$ Surbakti, Ramlan \& Didik Supriyanto. (2013). Partisipasi Warga Masyarakat dalam Proses Penyelenggaran Pemilihan Umum, p. 45.

6Prasetiyo, Adi. (2014). Perbandingan Prosedur Pemilihan Kepala Desa menurut Peraturan Daerah Kabupaten Grobogan Nomor 8 Tahun 2006 \& Menurut Undang-Undang Nomor 6 Tahun 2014 (Studi Kasus di Desa Rawoh Kec.Karang-Rayung Kab. Grobogan). Undergraduate thesis, Faculty of law UNISSULA.
} 
expression that law is the property of all humanity (the rule of law is the heritage of all mankind). ${ }^{7}$

The state of Indonesia is a state of law. Therefore, every state administration and government is always based on the rules and regulations, ${ }^{8}$ including regulations/laws regarding villages, namely Law Number 6 of 2014 concerning Villages (hereinafter referred to as the Village Law), the village automatically has protection and a legal umbrella in carrying out a legal relationship. ${ }^{9}$ In addition, with the stipulation of the village as a legal entity that can carry out legal relations, the village automatically has the authority to manage and be responsible for the interests of village government, even though the authority possessed by the village government is not as broad as the authority of the regional government. ${ }^{10}$

To carry out the function of village authority in regulating its government, it is necessary to have a village head who can carry out village government functions, this is confirmed in the Village Law. The village head has a significant role in regulating the running of the village government system in accordance with state regulations that have been mandated by the village head so that the creation of an independent and high-quality village. ${ }^{11}$

Because the village head is a community leader who is an ideal leader who acts as a protector for subordinates. The ideal leader is a qualified leader who can give influence to his subordinates to carry out direct instructions so that employees can work on time. The ideal leader is also able to provide instructions and direction needed by subordinates so that they complete tasks according to procedures and can complete tasks well. ${ }^{12}$

That by definition, local politics emphasizes decision-making, voting and public policies carried out at the local level when an individual or a small group of people can be involved and influence directly. Apart from the use of local political theory, the study in this study also uses the theory of decentralization and regional autonomy to support the use of local political theory. This is because discussing regional autonomy cannot be separated from the discussion of decentralization. In this case the State needs to take an action in facilitating local institutions by carrying out local emancipation through recognition by the state. ${ }^{13}$

From the political point of view, decentralization as a power play is intended to prevent the accumulation of power on one side only, which in turn can lead to tyranny. The administration of decentralization is seen as a democratizing action

${ }^{7}$ H. Jawade Hafidz, S.H., M.H. (2012). Malfungsi Han and Upaya Melakukan Rekonstruksi Sistemhukum Yang Ada Menuju Hukum Yang Melayani, Jurnal Hukum Unissula, Jurnal Hukum, Vol XXVIII, No. 2, December 2012.

${ }^{8}$ Maerani, Ira Alia S.H., M.H. (2012). Aplikasi Nilai-Nilai Islam dalam Peraturan Daerah (Perda) Tentang Pengelolaan Zakat \& Problematikanya Pada Era Otonomi Daerah Di Kota Semarang, Jurnal Hukum Unissula, Jurnal Hukum, Vol XXVIII, No. 2, December 2012.

9 Ridlwan, Z. (2015). Payung Hukum Pembentukan BUMDes, Fiat Justisia, 7 (3).

${ }^{10}$ Hasjimzoem, Y. (2014). Dinamika Hukum Pemerintahan Desa, Fiat Justisia Jurnal Ilmu Hukum, $8(3)$.

${ }^{11}$ Roza, D., \& Arliman, L. (2017). Peran Badan Permusyawaratan Desa di Dalam Pembangunan Desa \& Pengawasan Keuangan Desa, Padjadjaran Journal of Law, 4(3), 606-624.

12 http://jurnal.unissula.ac.id/index.php/cbam/article/view/313

${ }^{13}$ Astuti, T. P., \& Yulianto, Y. (2016). Good Governance Pengelolaan Keuangan Desa Menyongsong Berlakunya Undang-Undang No. 6 Tahun 2014, Berkala Akuntansi \& Keuangan Indonesia, 1 (1). 
to attract the people to participate in government and train themselves in exercising democratic rights.

Meanwhile, the discussion about village autonomy is often related to regional autonomy and is often even interpreted. Even though the terms regional autonomy and village autonomy are different from one another. In fact, if it is traced from the history of the existence of villages in Indonesia, it will be clear that basically village autonomy existed before regional autonomy. Where the autonomy possessed by the village is genuine, absolute and complete autonomy from the time when the village was formed in Indonesia and not a gift from the colonialist or the government. ${ }^{14}$

An explanation of village autonomy can refer to Soetardjo Kartohadikoesoemo's opinion that autonomy is something inherent in the village. According to him: “... rural areas are the oldest autonomous regions. It was founded before the birth of larger coordinating regions and before the birth of states (kingdoms). Therefore, he has the right to full autonomy. Its power does not only contain government in a narrow sense (bestuur), but also contains government in a broader sense (regering), because the village also has power over: courts, legislation (legislative), police, even defense. So the village area has a very broad autonomy, much broader than the autonomy of the larger regions that were established at a later date ...".15

In the decision-making process in the village, there are two kinds of decisions. First, decisions with a social perspective, which bind the community voluntarily, without clear sanctions. Second, decisions are made by formal village institutions established to carry out decision-making functions. The first form of decision, is often found in the social life of village communities, the decisionmaking process is carried out through a process of mutual consent, where previously the reasons for choosing an alternative were elaborated on by village elders or people considered to have certain authority. ${ }^{16}$

In the case of the implementation of voting using electronic voting equipment (e-voting) in the Pilkades, it is determined by the Regent by a Regent Decree. Pilkades are held simultaneously in one Regency, facilitated by the Regional Government by cooperating, namely in preparing for the implementation of electronic voting, the Regent cooperates with the Agency for the Assessment and Application of Technology (BPPT), so that implementation is more effective, efficient, and more coordinated from the security side. .

The legal basis for village head elections refers to the Regulation of the Minister of Home Affairs (Permendagri) Number 65 of 2017 Amendments to Permendagri Number 112 of 2014 concerning village head elections. In Article 6 of the Permendagri, the implementation of simultaneous village head elections is carried out through the stages of Preparation, Nomination, Voting and

\footnotetext{
14 Putra, B. A. (2015). Model Penyelesaian Perselisihan Hasil Pemilihan Kepala Desa, Kumpulan Jurnal Mahasiswa Fakultas Hukum, (1).

${ }^{15}$ Kartohadikoesomo, Soetardjo. (2014). Desa, Jakarta: PT. Balai Pustaka, p. 182.

16 Siti Rodhiyah \& Muhammad Harir Dosen Fakultas Hukum UNISSULA, Peranan Badan Permusyawaratan Desa (Bpd) Dalam Pembentukan Peraturan Desa Di Desa Krandon Kecamatan Guntur Kabupaten Demak, sitirodhiyah@unissula.ac.id, p.292.
} 
Determination. Where the village head election is the exercise of people's sovereignty in the village in order to elect a village head who is direct, general, free, secret, honest and fair.

In today's democratic life, we cannot be separated from what is known as public policy. These policies are found in the field of social welfare. So it can be concluded that public policy is a series of actions taken by the government which is oriented towards certain goals in order to solve public problems in the public interest. The policy to do something is contained in the provisions or legislation made by the government so that it has a binding and coercive nature. Because in a democratic life like today, we cannot be separated from what is called public policy. These policies are found in the field of social welfare. ${ }^{17}$

According to the author, studied with the theory of the State of law implementing the Village Head Election using the E-Voting Method in Pemalang Regency in 2018 there is still a conflict with the legal rules regulated above, namely the Minister of Home Affairs Regulation No. 65 of 2017 amendments to Permendagri No.112 of 2014 concerning Village Head Elections, which in accordance with Article 33 paragraph (1) Voting as referred to in Article 32 paragraph (2), shall be conducted by voting through ballots containing numbers, photos, and the name of the candidate or based on the customs of the local village community. (2) Voting for the election as referred to in paragraph (1) shall be conducted by casting a vote for one of the candidates in the ballot paper.

Before e-voting is introduced as an official method, it must trial or pilot projects in an election in a specific group (in a work or school environment), or a specific area (Pilkada or lower level), ${ }^{18}$ namely the election of the village head.

Elections or referendums that use electronic means of voting will speed up the vote counting process, produce accurate data, prevent errors and reduce the potential for fraud. ${ }^{19}$ The meaning of E-Voting is a method of voting and counting votes in a General Election using electronic devices. the purpose of using the EVoting system is to conduct cost-effective voting and to speed up the vote counting process. ${ }^{20}$

Where the implementation of the Village Head election using the e-voting method in Pemalang Regency is based on the Pemalang Regency Regional Regulation Voting as referred to in Article 56 paragraph (5) of Perda No.1 of 2015 concerning Pilkades is carried out by voting by punching a picture or voting sign images using electronic sound equipment. And Article 69 paragraph (5) Regent Regulation No. 36 of 2015 concerning the Rules for Implementing Regional Regulation No.1 of 2015 concerning Pilkades Voting as referred to in paragraph (4), is carried out by punching pictures or selecting images using voting instruments electronically.

\footnotetext{
17Winarno, Budi. (2002). Kebijakan Publik Teori \& Proses, Yogyakarta: Media Pressindo, p. 15.

18 Setiawaty, Diah Vishnu \& Sebastian. (2016). Rekapitulasi Elektronik: Langkah Strategis Dalam Pengembangan Teknologi Pemilu Di Indonesia. Jurnal Pemilu \& Demokrasi Yayasan Perludem, (9).

19 Caarls, Susanne. (2010). E-voting Handbook: Key Steps in the Implementation of E-enabled Elections. Council of Europe, p. 67.

${ }^{20}$ Badan Pengkajian \& Penerapan Teknologi. (2010). E-Voting Untuk Pemilu 2014. Retrieved from https://www.bppt.go.id/index.php/terkini/58-teknologi-material/425-e-voting.
} 
Judging from the provisions above, the implementation of Pilkades using the e-voting method in Pemalang Regency in 2018 is not in accordance with the provisions of the applicable legal regulations in accordance with Permendagri No.65 of 2017 concerning Amendments to Permendagri No.112 of 2014 concerning Village Head Elections, and Regional regulations and Regent Regulations made to legitimize the implementation of Pilkades using the e-voting method do not provide legal certainty because in these Regional Regulation (Perda) and (Governor Regulation (Pergub), the implementation of village heads can be done by punching pictures or using electronic voting equipment.

In the theory of the Democratic State, the implementation of Village head elections using the e-voting method in Pemalang Regency is in fact empirically not fulfilling the principles of direct, general, free and confidential, honest and fair where the neutrality of civil servants who are the Main Technical staff and field technical personnel who are appointed based on decisions The regent as a force who operationalizes the e-voting tool in the implementation of the Village head election is not very reflective of election independence as an effort to realize democratization in the elections desired by the people. Because in fact the formation of the Pilkades organizing committee in the village does not carry out its main duties and functions as the organizer of the Village head election.

Some of the supporting factors in the implementation of village head elections through the e-voting method in Pemalang Regency in 2018 were the formation of an election committee, the cost of selecting village heads, witnesses, and implementing voting. However, there are also inhibiting factors that need to be considered in implementation in the field which can become a legal issue, namely the involvement of Civil Servants who are the Main Technical Staff and field technical personnel, where the attitude of neutrality is taken into account and in the rules in the form of Act No. 2014 concerning Villages, Permendagri No.65 of 2017 concerning Amendments to Permendagri No.112 of 2014 concerning Village Head Elections, Perda 10 of 2018 amendments to Act No.

Looking at the empirical reality that the election of the Village head using the e-voting method in Pemalang Regency which is not based on the legal rules that become the implementing regulations, this is an obstacle to the realization of democratic values which are expected to be the main aspect of the Village Head election, sovereignty to vote on an overflow basis. Honest and justice which is the right of the community does not materialize properly due to engineering that violates legal norms in the implementation of Village head elections using the evoting method.

The government in the coming year will begin to prepare so that at least in the general election Indonesia is able to implement e-voting. A strong e-voting system and accurate results will certainly make everyone think again if they want to file a lawsuit to the Constitutional Court. Even if the e-voting process shows indications of fraud, the handling process will also be faster, easier and more transparent by conducting scientific investigations and digital forensic audits.

Pemalang Regency Government in this case said that the implementation of electronic voting (e-voting) will save in terms of time, cost and be very effective and efficient with more accurate results. Related to regulations (regulations) 
regarding the election of Village Heads using the e-voting system as stipulated in Pemalang Regent Regulation Number 47 of 2018 concerning Amendments to Pemalang Regent Regulation Number 36 of 2015 concerning Guidelines for Implementing Pemalang Regency Regional Regulations Number 1 of 2015 concerning Election Procedures Appointment and Dismissal of Village Heads.

Thus considering the existing field conditions, that Election of heads village in Pemalang Regency which were held by e-voting by utilizing the current development of information technology have brought major and fundamental changes to humans. This is because the use of e-voting technology is essentially a method of voting in general elections using electronic devices. So that e-voting can be an option in the implementation of elections (including village head elections) in the future related to the decision of the Constitutional Court Number 147/PUUVII/2009 which stipulates, whereas Law Number 32 Year 2004 Article 88 concerning Regional Government which contains "Voting for regional head and deputy regional head elections is conducted by casting a vote for one of the pairs of candidates in the ballot paper" is constitutional as long as it does not violate the principle of an overflow and fair election. Therefore e-voting can be carried out on a broader scale, including the general election for regional heads and deputy regional heads to the lowest level, namely the election of village heads. Remember that the Village Head Election by implementing an electronic system (e-voting) will save time, cost and be very effective and efficient with more accurate results.

Related to regulations (regulations) regarding the election of Village Heads using the e-voting system are also regulated in Pemalang Regent Regulation Number 47 of 2018 concerning Amendments to Pemalang Regent Regulation Number 36 of 2015 concerning Guidelines for Implementing Pemalang Regency Regional Regulations Number 1 of 2015 concerning Administration The method of Election, Appointment and Dismissal of Village Heads will be further refined so that aspects that can hinder future Village head elections are regulated in statutory regulations that specifically regulate village head elections.

In addition, it is also necessary to have laws and regulations governing Village Head Elections, such as the Village Head Election Law which contains rules on the Election, Appointment and Dismissal of Village Heads; how to settle Pilkades disputes by the competent authorities, in this case through the Judicial system in effect in Indonesia) not by the Regent and/or Mayor, considering that the Regent and/or Mayor are structural government positions/institutions not as judicial institutions that have the authority to complete village head election dispute.

\section{Conclusion}

That the implementation of the Village Head Election in Pemalang Regency through e-voting does not adhere to a good democratic system where the policy of implementing the Village Head election which is held is not based on the will and will of the people which normatively must be based on legal rules in the form of Law. Supporting factors in the implementation of village head elections through the e-voting method are the formation of an election committee, the cost of selecting village heads, witnesses, and the implementation of voting. The inhibiting factors are the lack of communication from the organizers to the public, the lack of 
availability of resources, the legality of procuring e-voting tools simultaneously, the legality of civil servants as experts/programmers/e-voting operators, the Legitimacy of Voters Boxes in the e-voting Pilkades, and Opportunities for Disputes in Village Head Elections. Prospects for implementing village head elections using the e-voting method in the future. Whereas the village head election held by utilizing the current development of information technology has brought big changes for humans, including e-voting. The use of computer technology in the implementation of voting is known as electronic voting (e-voting). It is a method of voting in general elections using electronic devices. E-voting will be an option in future elections.

\section{References}

Journals:

[1] H. Jawade Hafidz, (2012). Malfungsi Han and Upaya Melakukan Rekonstruksi Sistemhukum Yang Ada Menuju Hukum Yang Melayani, Jurnal Hukum Unissula, Jurnal Hukum, Vol XXVIII, No. 2, December 2012.

[2] Maerani, Ira Ali. (2012). Aplikasi Nilai-Nilai Islam dalam Peraturan Daerah (Perda) Tentang Pengelolaan Zakat \& Problematikanya Pada Era Otonomi Daerah Di Kota Semarang, Jurnal Hukum Unissula, Jurnal Hukum, Vol XXVIII, No. 2, December 2012.

[3] Maryanto, (2011). Urgensi Pembaharuan Hukum Indonesia Berdasarkan NilaiNilai Pancasila, Jurnal Hukum Unissula, Jurnal Hukum, Vol XXV, No. 1, April 2011.

Books:

[1] Astuti, T. P., \& Yulianto, Y. (2016). Good Governance Pengelolaan Keuangan Desa Menyongsong Berlakunya Undang-Undang No. 6 Tahun 2014, Berkala Akuntansi \& Keuangan Indonesia, 1 (1).

[2] Caarls, Susanne. (2010). E-voting Handbook: Key Steps in the Implementation of E-enabled Elections. Council of Europe

[3] Hasjimzoem, Y. (2014). Dinamika Hukum Pemerintahan Desa, Fiat Justisia Jurnal Ilmu Hukum, 8(3)

[4] Ishaaq. (2017). Metode Penelitian Hukum Penulisan Skripsi, Tesis, Serta Desertasi, Alfabeta, Bandung

[5] Kartohadikoesomo, Soetardjo. (2014). Desa, Jakarta: PT. Balai Pustaka

[6] Kuncoro, Adi. (2019). Perbandingan Prosedur Pemilihan Kepala Desa Berdasarkan Peraturan Daerah Kabupaten Grobogan Nomor 6 Tahun 2016 \& Menurut Undang-Undang Nomor 6 Tahun 2014 (Studi Kasus di Desa Rawoh Kec. Karang-Rayung Kab.Grobogan). Undergraduate thesis, Universitas Islam Sultan Agung

[7] Prasetiyo, Adi. (2014). Perbandingan Prosedur Pemilihan Kepala Desa menurut Peraturan Daerah Kabupaten Grobogan Nomor 8 Tahun 2006 \& Menurut Undang-Undang Nomor 6 Tahun 2014 (Studi Kasus di Desa Rawoh Kec.Karang-Rayung Kab. Grobogan). Undergraduate thesis, Faculty of law UNISSULA. 
[8] Putra, B. A. (2015). Model Penyelesaian Perselisihan Hasil Pemilihan Kepala Desa, Kumpulan Jurnal Mahasiswa Fakultas Hukum, (1)

[9] Ridlwan, Z. (2015). Payung Hukum Pembentukan BUMDes, Fiat Justisia, 7 (3)

[10] Roza, D., \& Arliman, L. (2017). Peran Badan Permusyawaratan Desa di Dalam Pembangunan Desa \& Pengawasan Keuangan Desa, Padjadjaran Journal of Law, 4(3)

[11] Setiawaty, Diah Vishnu \& Sebastian. (2016). Rekapitulasi Elektronik: Langkah Strategis Dalam Pengembangan Teknologi Pemilu Di Indonesia. Jurnal Pemilu \& Demokrasi Yayasan Perludem, (9)

[12] Siti Rodhiyah \& Muhammad Harir Dosen Fakultas Hukum UNISSULA, Peranan Badan Permusyawaratan Desa (Bpd) Dalam Pembentukan Peraturan Desa Di Desa Krandon Kecamatan Guntur Kabupaten Demak, sitirodhiyah@unissula.ac.id

[13] Surbakti, Ramlan \& Didik Supriyanto. (2013). Partisipasi Warga Masyarakat dalam Proses Penyelenggaran Pemilihan Umum

[14] Winarno, Budi. (2002). Kebijakan Publik Teori \& Proses, Yogyakarta: Media Pressindo

Internet:

[1] Bachri, Saiful. (2018). Bupati Pemalang Kritik Pilkades Voting Elektronik. Retrieved from Suara Merdeka website: https://www.suaramerdeka.com/news/baca/121237/bupati-pemalangkritik-

[2] Badan Pengkajian \& Penerapan Teknologi. (2010). E-Voting Untuk Pemilu 2014. Retrieved from https://www.bppt.go.id/index.php/terkini/58teknologi-material/425-e-voting.

[3] http://jurnal.unissula.ac.id/index.php/cbam/article/view/313 